\title{
DIGITIZATION OF SLIDE FILM (35mm) - TRANSFER, POSTPRODUCTION, ADMISSIBLE CHANGES
}

\author{
losif Astrukov, ioshertz@abv.bg \\ Institute of Art Studies at BAS, Sofia, Bulgaria
}

\begin{abstract}
One of the most widespread photography formats before digitization, both for professional and amateur use, was the slide film (35mm, Leica format). Due to its compact size, compared to medium and large formats, this equipment was preferred by all photo reporters, photographs of the wild nature (probably the best known was the ones of the National Geographic magazine) and of course for the general people, creating family photos. Slides were the common way of presenting, when images had to be shown at wide audience. They appeared also in art - in galleries and on stage. For that reason there is enormous material shot on this medium, transferred regularly in digital format. The digitization itself is constantly changing and sometimes the same image is digitized numerous times. In this material I will follow the basic ways of digitization and the changes that occur. Important problem of the digital transfer still remains the limit of admissible postproduction, which inevitably is modifying the initial image.
\end{abstract}

Keywords: Photography, Slides, Digitization, 35mm

\section{АИГИТАЛИЗАЦИЯ НА АИАПОЗИТИВИ (35ММ) - ПРОМЕНИ, ОБРАБОТКА, АОПУСТИМИ ГРАНИЦИ}

\section{Йосифр Аструков, ioshertz@abv.bg}

Институт за изследване на изкуствата при БАН, Софрия, България

Резюме: ЕАин от най-разпространения фотографрски форомат преди масовото навлизане на Аигиталната техника, както за профресионална така и за любителска употреба, бяха Аиапозитивите (З5мм, ^айка фрормат). Порали значително покомпактните си размери от средния и голям фрормат, тази техника беше предпочитана от всички фоторепортери, фотографри на Аивата природа (вероятно най-известни бяха тези на списанието 
National Geographic) и разбира се хората сьздаващи просто семейни спомени. Аиапозитива беше и основно средство за презентации, когато образите трябваше $А$ бъдат прожектирани преА голяма аудитория. Те присъстваха и в изкуството, както в галерии така и в сценичните изкуства. По тази причина има натрупан огромен материал на този носител, периодично прехвърлян в Аигитален формат. Самата Аигитална технология се променя непрестанно, поради което елно и също произведение понякога се Аигитализира многократно. В настоящия материал ще прослеАя виАовете Аигитализация и настьпващите промени в изображението. Сьществен проблем остава границата на допустима обработка, която неизбежно променя пьрвичния образ.

КАючови Ауми: фротографрия, Аиапозитиви, Аигитализация, 35мм

Появата на Kodachrome през 1935 г., разработен от Kodak, бележи началото на масовия цветен Аиапозитивен филм, който ще се използва в продьлжение на 75 голини и ще запечата цяла еАна епоха'.

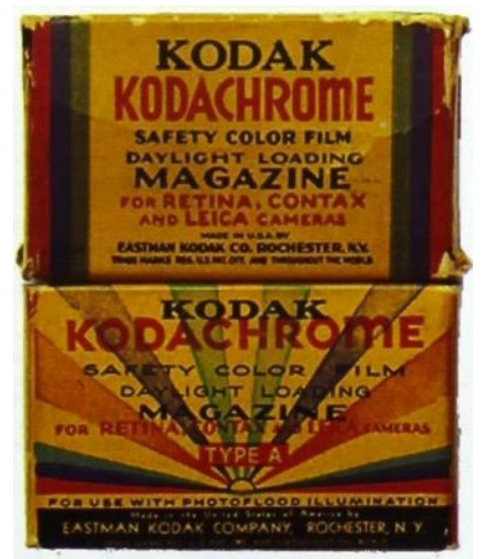

\section{Фиг.1. ИАюстрация на първите фимми}

Историята на цветното изображение показва Аьлга еволюция (Harris, 1954, рр. 46-59), на практика в продьлжение на цялата история на фротографията, като тя продь^жава и Анес в Аигиталните технологии. Аиапозитивите в частност също преминават редица усъвършенствания, Аостигайки много високо качество на изображението, за което бяха предпочитани от много продеесионалисти. През 2009 г. Коdak обяви спирането на Kodachrome, порали ограниченото търсене и наличието на

1 RPS Journal July/August 2009, p.324, https://archive.rps.org/archive/volume-149 (Viewed at 23-02-2021) 
по-нови поколения Аиапозитивни фрилми². Посленната ролка беше предоставена на фоотографа Стив Макъри, чиято профресионална кариера и постижения са тясно свързани с този ффилм, а самото й снимане Аокументирано от National Geographic ${ }^{3}$. 3a съжаление тенденцията на свиване на произволството и предлагането на фри^ми продьлжи с напредването на Аигиталната техника и през 2013 г. Коdak обявиха спирането въобще на Аиапозитивите. Самата компания преживя трусове и фолиити, но все пак оцеля4. Същото се случи и с останалите производители, някои от които изчезнаха напьлно (Agfa, Konica), a Fujifilm релуцираха значително асортимента. Цените на тези, които останаха се влигнаха значително и продьлжават $а$ а растат. Паралоксално послеАните няколко ГоАИни се наблюАава ръст на използването на

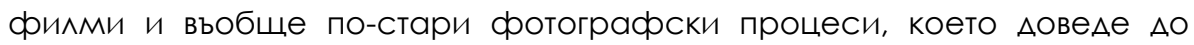
възстановяване на произво сството на Аиапозитиви от Kodak през 2017 г., но вече само с еАин-еАинствен молел ${ }^{5}$. 3а сравнение Ektachrome серията някога съставляваше 4-5 вила филми (G, GX, VS, E200, Tungsten), с нюанси в зърнистост, чувствителност, цветопредаване, цветна температура и Аруги. Пускането на позитивен оримм беше свьрзано и с опита им Аа възродят Аюбителското кино на супер 8мм с нова камера6. НеотАавна Kodak възстановиха и най-масовия цветен негатив Kodak Pro Foto 100, сега Pro Image7. Fujifilm също възстановиха черно бял фрилм Neopan Across, който беше спрян в продьлжение на голина.

\footnotetext{
2 RPS Journal July/August 2009, p.324, https://archive.rps.org/archive/volume-149 (Viewed at 23-02-2021)

${ }^{3}$ National Geographic: The Last Roll of Kodachrome, https://www.youtube.com/watch? v=DUL6MBVKVLI\&lisł=PLrAKxjN4yqyY_TjVkx743cd9qK GNQ5LDs\&index=94 (Viewed at 19-02-2021)

4 Eastman Kodak Files for Bankruptcy, https://dealbook.nytimes.com/2012/01/19/eastman-kodak-files-for-bankruptcy/ (Viewed at 19-02-2021) 5 CES 2017: Kodak Brings Back Ektachrome Color Reversal Film, https://www.bhphotovideo.com/explora/photography/news/ces-2017-kodak-bringsback-ektachrome-color-reversal-film (Viewed at 22-02-2021) 6 Kodak Announces Super 8 Revival with New Camera, https://www.bhphotovideo.com/explora/video/news/kodak-announces-super-8revival-new-camera (Viewed at 22-02-2021) 7 Kodak Pro Image 100 Color Negative Film.... https://www.bhphotovideo.com/c/product/1476367REG/kodak 6034466 kodak_proimage 100 135_36.html (Viewed at 25-02-2021)
} 
Тези процеси показват колко несигурно е често пьти предсказаното ни технологично бъдеще, което преди десетилетие се смяташе за ултимативно Аигитално. Търговците на фоотографрска техника посочват 2010 голина за връх в продажбите на дигитална техника, слеА който спала върви само налолу.

\section{Digital Camera Sales Dropped by $87 \%$ Since 2010}

Worldwide digital camera shipments by CIPA members

$$
\begin{aligned}
& \text { Cameras with built-in lens } \\
& \text { Cameras with interchangeable lens }
\end{aligned}
$$

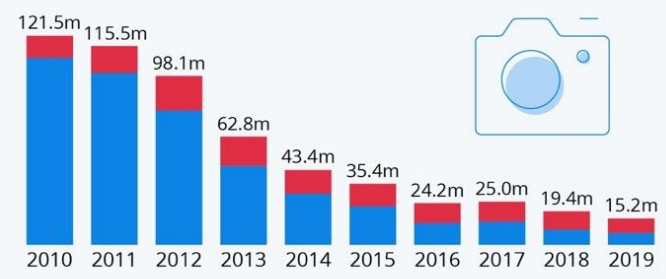

Camera \& Imaging Products Association (CIPA) is an international industry association. Members include Olympus, Casio, Canon, Kodak, Sony and Nikon among others. Source: CIPA

\section{(c) (i) $\ominus$}

\section{statista $\boldsymbol{Y}$}

\section{Фиг.2. Статистика на продажбите на фотографска техника}

2020 голина следва Аа са още по-ниски, зарали кризисната ситуация ${ }^{8}$. Различни причини се посочват за тази тенденция - развитието на смартфоните или Аостигането на плато в технологичното развитие, когато хората не желаят Аа сменят наличната техника. Вероятно са комбинация от фоктори, които в крайна сметка водят Ао това насищане, Аори омръзване, ъй като технологиите Анес имат и модно измерение, и в крайна сметка води АО възражАането на старите фротографрски процеси, което наблюАаваме.

През целия този периол от приблизително Аве десетилетия, Аигитализацията на фоиммовите изображения също се променяше, еволюираше, сменяше носителите и т.н., на практика слеАваше развитието на Аигитализацията. Но ако поглеАнем сега назал, бихме могли $а$ а разграничим Ава основни метода - сканиране и преснимане.

\footnotetext{
8 Неорормално, оффициалните представители от Photosynthesis сполелиха, че отчитат спаА С ОКо^о $40 \%$
} 
Парадоксалното на Аигитализацията е, че всички варианти са колкото разАични, ТОАКова И еАНакви.

Всяко прехвьрляне има своите нюанси, но генерално изображението е същото. Ако се върнем към фрундамента на процеса, какво означава $а$ а се Аигитализира елно изображение? Аигиталният образ всъщност е записан Авоичен коА в $\Delta$ ален компютьрен фрайл, койо системата компютьр-софртуер-екран-принтер или Аруга машина разчита и преобразува в светлина или мастило, което човешкото око може $\Delta а$ възприеме. В това отношение еАин от профресорите по фротографрия в НАТФИЗ „Крьстьо Сарафров", беше много прав, когато по време на

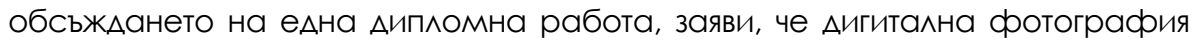
няма - може $А$ а се говори еАинствено за Аигитално колиране на образи. И

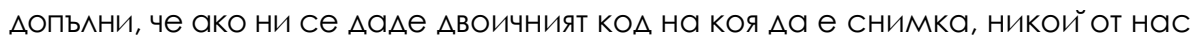
няма $а$ в вили в него образа. Тогава ми се стори изключително паралоксално това твьрдение, още повече изречено преди десетина гоАини, в началото на Аигитализацията и истерията около нея. Но времето и технологиите все повече Аоказват този постулат. Аа се Аигитализира еАно изображение означава $а$ а се колира в нули и еАиници инорормацията от него, като вариациите са практически безкрайн. Именно тук е основният

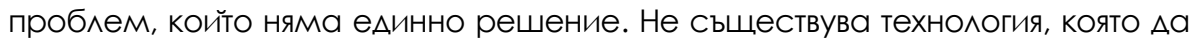
прехвърля Аиректно, еАно Към еАно аналогово Към Аигитално изображение. Полобно на процеса, по койо се възпроизвежла, образът се колира, но в обратен рел - светлина-матрица (сензор)-софртуер-компютьр-фрай. И тук започват многото възможности. Всяка система от матрица и софртуер Аават своите цветове например, като всеки производител твърди, че са „верни“. Но спрямо какво? Този казус не е нов за фотографията - всеки произволител (Kodak, Fuji, Agfa, Konica), виА фрилм (негатив, Аиапозитив) и разновиАности в рамките на $А$ ален произволител и фоимм (Velvia, Provia, Sensia - Аиапозитиви на Fuji напр.) имаха различно цветопредаване и характеристики като цяло. Много от тях вече не се произвежлат, като имаше разработени и специални профоилирани фоимми - портретни, като ^егендарната Portra ${ }^{9}$ на Kodak, все още съществуваща и високо ценена, прес фимми като Fujicolor Press 800, или специализирани за сватби.

${ }_{9}$ Color | Kodak Alaris, https://imaging.kodakalaris.com/photographers-photoprinting/film/color (Viewed at 19-02-2021) 
Всеки от тях беше съответно с подобрени характеристики за конкретната ситуация - мекота и естествени тонове при портретните менти, подобрена Аинамика и предаване на бялото за сватби и т.н. При Аигиталните фотоапарати аналогични са цветните профили - Standard, Portrait, Vivid, Landscape, Neutral и Аруги, като има вьзможност за създаване на профили или Аобавяне на специфични, невключени от производителя10. Много от тях са съзАадени като симулация на споменатите легендарни фрилми. Особеното в случая обаче е, че Standard профрильт на Canon например, не сьвпала сьс Standard при Nikon, Sony или Fujill. Нещо повече - дори в рамките на един производител, те се различават при различните модели и поколения фротоапарати. Същото важи и за скенерите. ОтАелно - всеки виА фрайл има своята компресия, освен определени, за които се приема, че съдьржат инорормацията в суров виА. Всеки екран има своята цветна калибрация, различните принтери и хартии - също, както и предават Аинамика, контраст и острота различно. ЕАин и същи орайл често пьти изглежАа много различно на Ава различни екрана. Сензорите имат и различна резолюция - всяко слеАващо поколение е с по-висока. Аигитализацията се оказа еАин непрекьснат процес, следващ развитието на технологията. ^огично иАва въпросът - има ^и граница? И колко е всъщност резолюцията на филма вьобще? А на копираната снимка? Този Аебат се възобновява на всяка технологична стьпка, обикновено с призиви че „вече е напьлно Аостатьчна“. И впоследствие иАва по-висока.

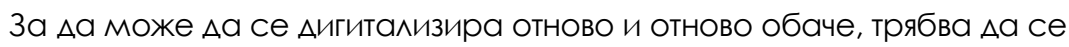
съхраняват оригиналите (аналоговите пьрвоизточници). В противен случай произведението остава „замрьзнало“ в своето Аигитално копие. Фотографията борави с голямо разнообразие от носители. Всеки има своя специфика и налага различен поАХОА за Аигитализация.

През 2012 г. излиза изследването на Гай Бърнс (Guy Burns, 2012: p. 3) "Изкуството и науката в репродуцирането на Kodachrome". Струва ми се, че то

\footnotetext{
10 Този сайт предлага десетки профрили за фотоапарати Nikon - Nikon Picture Control Editor, https://nikonpc.com (Viewed at 19-02-2021)

11 В интернет има Аесетки сравнения - ето еАно, което сравнява фротоапаратите Canon 5D mark III и Nikon D800, като разбира се оптиката също влияе - Color Comparison: Canon 5D Mark III and Nikon D800..., https://cdtobie.wordpress.com/2012/08/27/color-comparison-canon-5d-mark-IIl-andnikon-d800/ (Viewed at 19-02-2021)
} 
няма статут на реално научно изследване, но начинът, по койо е изгралено, аналитичния поАхоА и обем (234с.) за мен е напьлНо равностойно на изследване, при това най-Аоброто, на което съм попалал. Обърнете внимание на заглавието - не е просто сканиране или Аигитализиране, той използва Аумите наука и изкуство за репродуциране. Гай Бърнс полага огромни усилия Аa систематизира различните начини за Аигитализация на тази ^ента (Guy Burns, 2012: p. 3):

"Initial scans were poor and I was not prepared to go ahead until I sorted out the problems. Once I started scanning I needed to be sure I was obtaining the best results. I didn't want to reach the end of the project only to realise that I had scanned in an inferior way."

"Първоначалните сканирани изображения бяха ^оши и аз не желаех $\Delta а$ прольлжа, преди ла разреша проблемите. Веднъж започнал $а$ а сканирам, исках $А$ съм сигурен, че получавам найлобрите резултати. Не желаех $А$ стигна $\Delta$ о края на проекта само за $А$ о осъзная, че съм сканирал посреАствено."12

Той анализира полробно различните термини и ефекти, калибрациите на скенерите, структурата на Kodachrome ^ентата и т.н. Взима като еталон 20 Kodachrome ииапзитива, пьрвият от които е специален чарт и Аигитализира всяко изображение по три различни начина - плосък скенер (Epson V700) (фриг.3)., специализиран ффилмов скенер (Nikon Coolscan V ED) (фриг.4) и преснимане с фоотоапарат (Nikon D700) (ффиг.5). За по-нагленна представа на трите варианта, ето как изглежлат те:

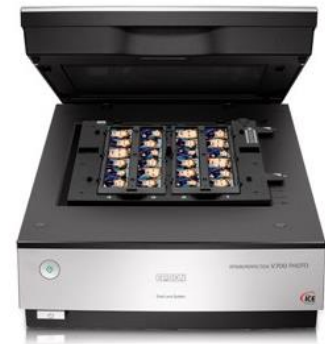

Фиг.3. Epson V700

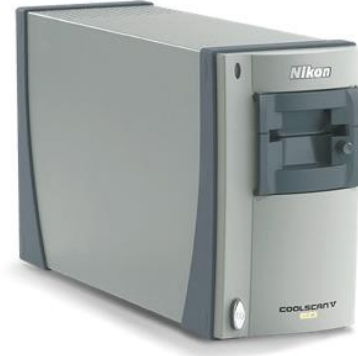

Фиг.4. Nikon Coolscan V ED

12 Burns, Guy. (2009). The Art and Science of Reproducing Kodachrome, p. 3 (Guy Burns, 2012: p. 3) 


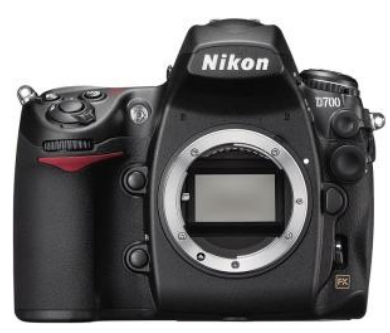

Фиг.5. Nikon D700

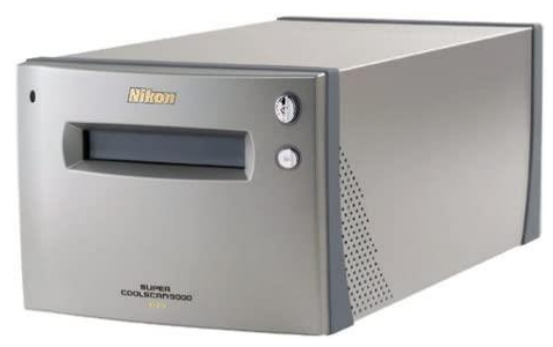

Фиг.6. Nikon Coolscan 9000

Освен тези три основни начина, на стр. 75 от изследването споменава още няколко скенера и така наречения от него „wet scan" вероятно барабанен скенер, койо в зората на дигитализацията се смяташе за върхова технология, но от много голини вече не се използва. Той самият също не го илентиоицира (марка, молел) и ползва пряко, аз Аично също никога не съм има^ Аосег или вижАал сканирани сурови изображения и сравнения с този тип сканиране. Може $\Delta$ a се прилага и на други скенери, но както сам обяснява, недостатькът при него е в контактната технология - за $\Delta$ a cе сканира, ^ентата се е "залепяла" временно със специално вещество, което има същия коефициент на пречупване на светлината, както самата стъклена повърхност ${ }^{13}$.

Приема се, че това вещество е безвренно за фрилма и се измива без остатьк, но повечето фотографии предпочитат да избягват мокрене и Аиректен досег с оригиналите. Това важи в още по-голяма степен за архивните фрилми - всеки пряк контакт, ффизически или с химикали се избягва. Техниката, която използва Гай Бърнс (Guy Burns), е била върхова за тогава (2010-12 голина), като двата скенера са принципно различни.

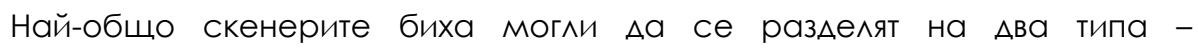
специализирани за фолми, какъвто е показаният от серията Nikon Coolscan (фриг.4, 6). и т. нар. плоськ скенер, разработен основно за отпечатани изображения.

Необходимостта от различните виАове Аигитализации иАва от споменатото вече голямо разнообразие от фооторафоски фоормати. Специализираният фоиммов скенер Nikon Coolscan V ED например може

13 Пример за такъв „,wet scan“ на Epson скенер - How to wetmount film with..., https://www.youtube.com/watch? $v=f u 25 r Y Y W i R U \& l i s t=F L i j 00 h g v v s s h$ uGy9vDmwAw\&in dex=1 (Viewed at 22-02-2021) 
да сканира единствено 35мм лайка фрормат (24х36 мм). За средния формат (6х6 см, 6×7 CM, 6×9 см) Nikon разработват Аруга серия фриммови скенери - 8000/9000 (фриг.6).

Големите фоотографоски фоормати (9x13 cм, $10 \times 15 \mathrm{~cm})$ могат $\Delta$ a се сканират само на плоски скенери от типа на посочения Epson или преснимани (фриг.3). В това отношение преснимането е може би найуниверсалният метол - с помощта на приставки и увеличение или софртуер за създаване на панорамни изображения, той може $\Delta а$ Аигитализира от най-малките филмови фрормати Ао картини. Най-често Анес художествените произведения се Аигитализират по подобен начин. Кьм скенерите трябва $\Delta a$ се добавят още няколко типа, широко използвани и Ао сега. Това са специализираните фрилмови скенери към мини ^абовете, които работят основно с 35мм фоимми (фриг.7).

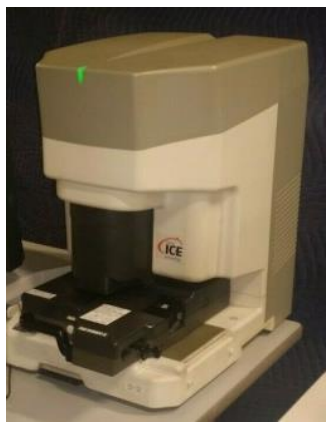

Фиг.7. Noritsu film scanner S2

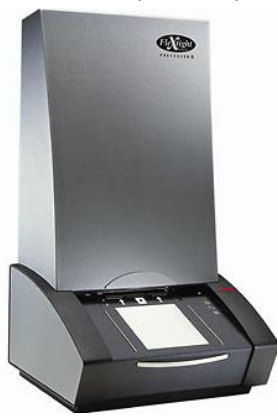

Фиг.8. Imacon

Сьзалени $а$ а работят към фоотоателиетата, те са автоматизирани за големи обеми за кратко време, като софртуера им е улеснен за прехвьрляне Аиректно кьм копирната машина. ЕАин цял филм се сканира за броени минути. Този тип скенери и мосега са незаменими, когато е необхолимо бързо да се сканират много фиимии в ниска резолюция, за т. нар. preview (бърз преглел). Но за това е необхолимо те $\Delta$ а не са нарязани и класирани или рамкирани. Недостатъците са честото налраскване, при автоматичното преминаване на цялата лента през механизма, относително малкия контрол върху сканираното изображение и ниската резолюция. В началото те работеха с 2-3000 dрі, като послеАните молели стигат 4-500 dрі. Това е общ проблем за всички скенери, тъй като компаниите спряха разработките и Аори полАръжката им, порали намаленото пазарно 
търсене. Емблематичните скенери на Nikon например са произвежлани Ао 2004 г. ${ }^{14}$. Те и Ао момента остават еАни от най-Аобрите, като цената им на старо се покачи неколкократно. Това е ефектьт на пазарните принципи. Масово скенерите, които се ползват и $\Delta о$ момента, са произведени преАи повече от Аесетина години и с максимална резолюция от 4000 dрі. Приравнено към резолюцията на фотоапаратите, за 35мм е в Аиапазона на 12-20 Мрх. За сравнение посленните молели профресионални фотоапарати Аостигат 40-50 Мрх ${ }^{15}$. Аругият широкоразпространен вид скенер е от сериите на Imacon, по-късно взети от компанията Hasselblad (фоиг.8).

Порали вертикалната си конструкция, тези скенери са почти универсални - Авижението на сензора по височина $А$ ава възможност за сканиране на много различни фрормати, фри^мови и отпечатани. СлеА преминаването им към Hasselblad, технологията имаше възможност $\Delta а$ се Аоразвие още няколко голини, преАи също да бъдат спрени. Последните няколко моле^а (Flextight X1, X3, X516), стигат резолюции от 6-8000 dpi.

Порали високата им цена тук масово се използват все още старите модели, като аз не съм има^ възможност Аа сравнявам пряко резултати от послеАните. Различните технологии на Аигитализиране Аават и различни резултати, като тук се вкАючват и вариациите на всеки метол поколение скенер, вил матрица, оптика и тип използвана светлина (халогенна, LED, импулсна, Аневна) и, разбира се, софртуер. Описаните скенери представят основните видове, без в никакъв случай $а$ са изчерпателен списък ${ }^{17}$. Всеки скенер има своя софртуер, като съществуват и специално разработени софтуери само за сканиране,

\footnotetext{
14 Статии за полАрьжка,

https://www.nikonimgsupport.com/eu/BV_article? articleNo=000006470\& configured $=1$ \& lang=en_GB (Viewed at 20-02-2021)

15 Nikon | Imaging Products..., https://imaging.nikon.com/lineup/dslr/d850/ (Viewed at 20-02-2021)

16 uk_x5_x1_datasheet_v4.pdf, https://cdn.hasselblad.com/manuals/flextight/uk x5 xl datasheet_v4.pdf (Viewed at 20-02-2021)

17 Този сай $а$ ава полробни ревюта и сравнения на десетки скенери - Detailed test reports..., http://www.filmscanner.info/en/FilmscannerTestberichte.html (Viewed at 2202-2021). Виктор Герасимов също прави сравнение на много скенери и последните гоАини работи профресионално по Аигитализацията на всякакви фотографоски формати - Сравнение на скенери, http://filmscan.pro/comparisonoffilmscanners/?fbclid=lwAR36jal8 J2gJJxOPethnwDJoR G66_IdmAQY9uN646HDIgZpIN9z9jVOFvk (Viewed at 22-02-2021)
} 
които работят с широк спектьр от скенери ${ }^{18}$. Всички те сьАьржат и много профоили (presets), предварително залалени за различните ленти, с илеята, че всяка лента има различна специфика и точно този профил би

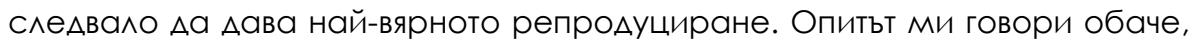
че това рядко е така. Гай Бърнс (Guy Burns) подробно описва технологията на сьзАаване на цветен профил за Kodachrome, с ета^он IT8 на Kodak, като накрая завьрша с Аумите (Burns, 2009: р. 15):

"My experience with Kodak's IT8 target when used to calibrate the Epson V700, and to a lesser extend the Coolscan V ED, is that the end result may not justify the time and expense. Editing has more significant effect on the final image than calibrating."

„Моят опит с Kodak's IT8 еталон използван за калибрация на Epson V700 и в по-малка степен на Coolscan V ED е, че крайният резултат може $\Delta а$ не е оправдае времето и разхолите. Обработката има значително по-голям еорект върху ориналното изображение от калибрацията. "19

Ето пример за негативен кальр, сканиран на $А$ ва различни скенера, с вариация на софтуера при втория скенер (фоиг.9):

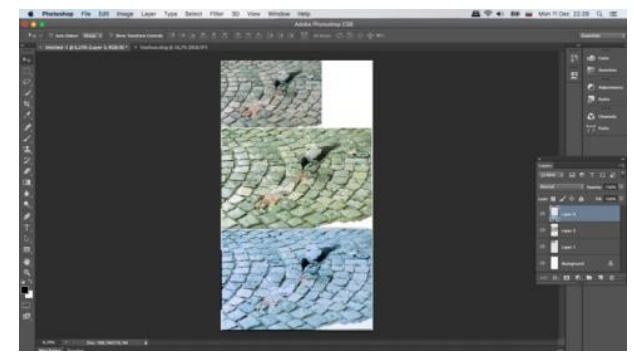

Фиг.9. КаАър сканиран по 3 размични начина

От горе налолу съответно - на мини $а$ аб във фоотоателие, на Nikon Coolscan 9000 с оригиналния софртуер, най-Аолу същия скенер, но с Vuescan. Калрите са в суров необработен виА и default настройки на софртуера. Съществуват и технологии за автоматично изчистване на прах и драскотини, каквато е технологията Digital ICE, която сканира изображението на Ава пьти, веАнъж във видимия Аиапазон и веднъж в

18 Примери за полобен софртуер са SilverFast http://www.silverfast.com/scan-nersoftware/en.html (Viewed at 20-02-2021) n VueScan - VueScan Scanner Software..., https://www.hamrick.com (Viewed at 20-02-2021)

19 Burns, Guy. (2009). The Art and Science of Reproducing Kodachrome, p. 15 (Burns, 2009: p. 15) 
иноррачервения, като при наслагването елиминира и замества софртуерно петната. Всичко това отново влияе на фриналното изображение и съвсем естествено има дебати за и против, кога $\Delta а$ се използва и в каква степен ${ }^{20}$. Гай Бърнс (Guy Burns) пише резервирано за ICE технологията. При черно-бели негативи е неприложима зарали среброто в емулсията. За полобряване на Аинамиката се прилага multipass scanning или HDR (high dynamic range) при преснимане, което по същество представлява наслагване на няколко изображения с различна експозиция, за $\Delta$ а се получи повече инорормация в тъмните и светлите места на снимката. Това разбира се отново повлиява цялостно изображението, не само Аинамиката. През голините ми се е налагало Аа сканирам многократно еАни и същи калри, основно З5мм Аиапозитиви.

Поставени еАин Ао Аруг сега, суровите или обработени изображения на практика проследяват развитието на технологията $\Delta$ о момента, но също така показват и колко относителна може $\Delta а$ бъле Аигитализацията. Всички специалисти и фротографри имат свои предпочитания, но моя опит показва, че най-Аобрият начин за Аигитализиране на диапозитиви към момента е чрез преснимане. Причините за това са няколко. На пьрво място е резолюцията. Както вече споменах, камерите в момента притежават сензори с по-висока резолюция от порядька на 2-3 пьти. Но освен резолюцията, всичко останали параметри също са полобрени значително - Аинамика, острота, контраст, цветопредаване... Интернет изобилства от варианти за преснимане на всякакви вилове лента, най-често ръчно приголени.

За лайка формат те неизбежно сьльржат камера с макро обектив или полобно приближение, към който се закача приставка или пригажАат светеща по Аожка. Технологията, която аз използвам и смятам за оптимална, съАьржа тяло Nikon (D810 или D850), обектив AF-S Micro Nikkor 60mm и приставката ES-1 с прехолHик BR-5: (фриг.10, 11 )

20 dpreview.com:..., https://www.dpreview.com/forums/thread/1904182 (Viewed at 2002-2021) 


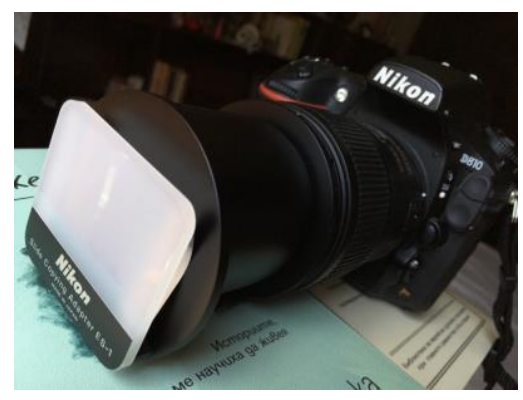

Фиг.10. Nikon D810 + AF-S Micro-Nikkor $60 \mathrm{~mm}+\mathrm{BR}-5+\mathrm{ES}-1$

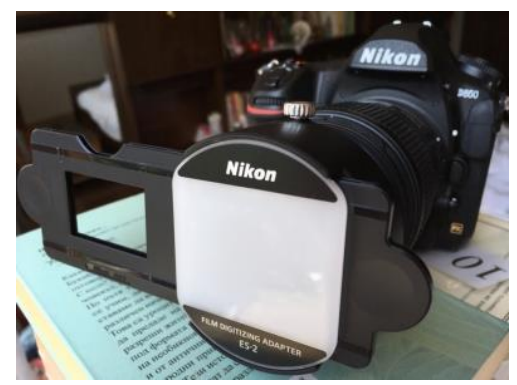

Фиг.11. Nikon D850 + AF-S Micro-Nikkor $60 \mathrm{~mm}+\mathrm{BR}-5+\mathrm{ES}-2$

Приставката ES-1 е оригинално разработена още прели Аигитализацията, когато има необходимост от правене на копия на Аиапозитивите, тъй като често пьти те представляват еАин-еАинствен оригинал. Преди няколко години Nikon пуснаха втора - ES-2, с възможности за различно нарязани З5мм ленти, като послеАният модеА Nikon D850 има възможност за автоматично обработване на негативи (но само в JPEG орормат) ${ }^{21}$.

Различни светлинни Източници могат $а \mathrm{a}$ бъАат Използвани (постоянни или импулсни), аз зальлжително работя на пряка сльнчева светлина, тьй като тя е еАинствената с пьлен спектьр и осигурява найоптима^но цветопредаване, както и е Аостатьчно сияна за Аа "отвори“" тьмните части на кальра. Сьщо така съвременните камери сьм забелязал, че са най-оптимално калибрирани за дневната светлина.

21 Последните години се засили тенденцията на преснимане, което Аоведе Ао появата на много Аопьлнителен софтуер за обработка на негативи - Grain2Pixel Fllm Photography Tools, https://grain2pixel.com, (Viewed at 20-02-2021), Negative Lab Pro, https://www.negativelabpro.com (Viewed at 20-02-2021) 


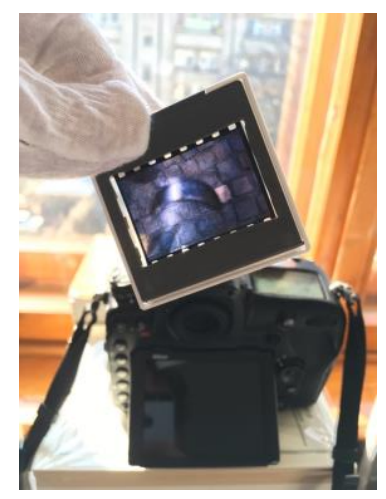

Фиг.12. ПреАи поставяне в приставката, на пряка слънчева

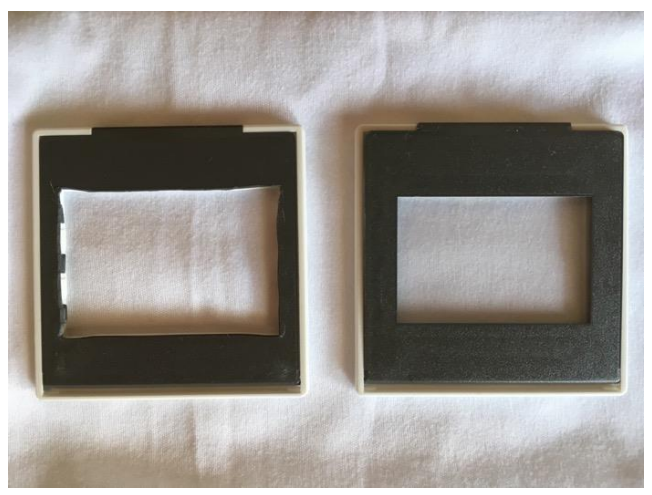

Фиг.13. Сравнени - изрязана и без стък^а към оригинална рамка светАина

Рамките оригинално се проектират $\Delta а$ застьпват

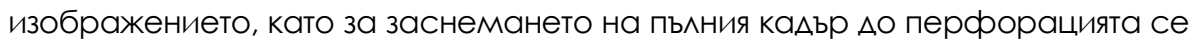
налага $а$ а бъдат изрязани с 1-2 мм и разбира се без стькла (фриг.12, 13). Част от предимствата на този метол са, че рамката до голяма степен Аьржи лентата изпьната (фрункцията на дьржачите при скенерите) и може $\Delta а$ се изчисти непосредствено преди поставяне в приставката, което почти премахва нужАата от ретуш впослеАствие. При много от скенерите ори^ма остава навън слеА почистването или преминава многократно, събирайки наново прах. За самата експозиция използвам режим на приоритетна бленла (А), тъй като калрите могат $а$ бъ бат много различни и това осигурява правилно експониране спрямо всеки еАин, с фоиксирана постоянна бленла f8. Тралиционно обективите са с

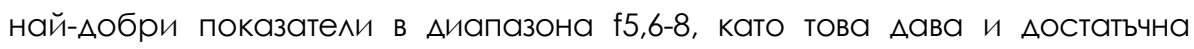
Аьлбочина на рязкост, въпреки че в случая има възможност и за избор на фокусна точка. Меренето е добре $л а$ бъле по целия кальр или с тежест в центьра. При тази постановка вариации на Аигитализацията се получават само от фотоапарата и промяна на настройките. Това са - поколение техника, фрайлов фрормат и цветен профии. От избора на поколение техника зависи основно резолюцията. Файловият орормат и цветния профри^ са взаимосвързани и Аават много нюанси на Аигиталния каАър.

Ако се използва суровият фрай^ (NEF при Nikon), цветния профри^ може $а$ а се променя при обработката. Но опита ми говори, че 
създаването на HDR успява $\Delta \mathrm{a}$ „извали“ много повече индрормация от кальра и ла го пресьздале по-алекватно (фриг.14).

Ето еАин поАобен HDR тест:

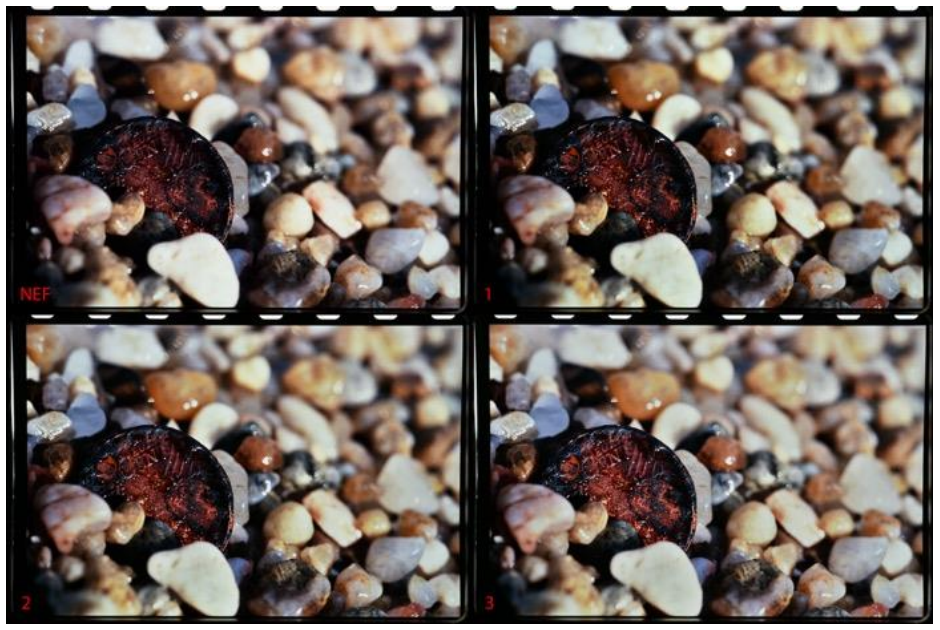

Фиг.14. NEF спрямо HDR с разАична стъпка

Разликите са ясно виАими при увеличение на голям екран. Новите фотоапарати имат вградена опция за HDR през три стьпки - 1, 2 и 3, които са използвани на теста по-горе. Възможно е $а$ се направи и ръчно. В този случай фотоапаратьт не може съзАава суров фоай^ (NEF), за това използвам некомпресирания фоормат TIFF.

Неговият недостатьк е огромния размер, често нал 100 Мb при новите тела. При този фрайлов орормат обаче, цветният профри^ остава фриксиран. Това са сурови калри, при които е променян еАинствено цветния профри^ на фротоапарата (фриг.15): 


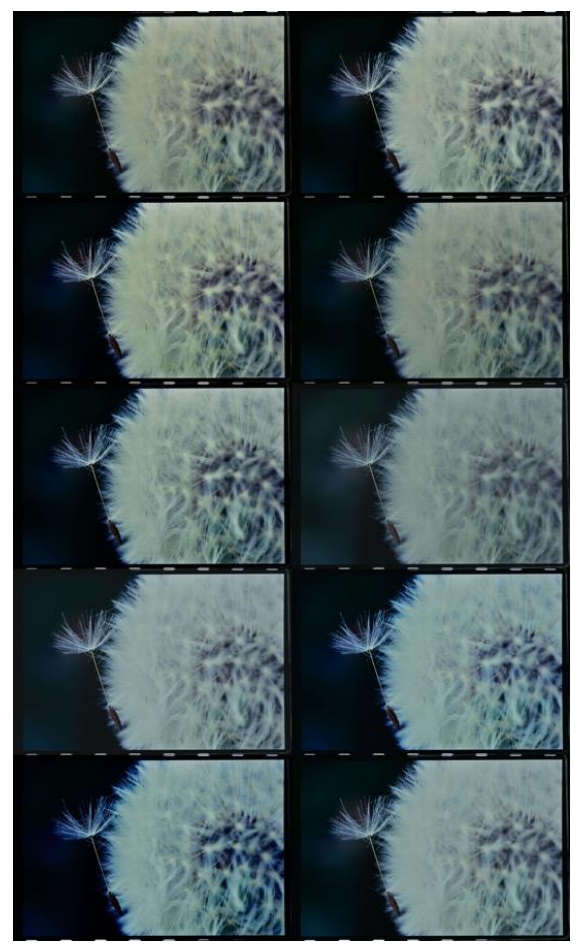

Фиг.15. Нюанси при промяна на цветния профим

Отново разликите са ясно виАими увеличени на монитор. Обикновено Standard и Portrait профииите Аават най-Аобри резултати. Тъй като на Аисплеите на самите фротоапарати е трулно $\Delta а$ се определи най-Аобрият резултат, обикновено правя вариации с трите HDR стьпки и различни цветни профоили, от които впослеАствие на голям екран избирам най-оптималният.

Повечето гледат на този метол на Аигитализиране като най-бърз, но истината е, че качество и бързина са като скачени сълове. Качественото прехвьрляне винаги отнема време. Ако в случая разглежламе еАинствено сработването на затвора на фотоапарата, който е части от секундата, да, имаме бързина. Но предварителната подготовка, прехвърлянето на кальра в рамките, почистване и т.н. е времеемък процес. Разбира се той съществува и при сканиране, но се различава специфиино за всеки отлелен молел. 
В изследването си Гай Бьрнс (Guy Burns) показва интересна конструкция (стр. 234), която синхронизира диапроектор Kodak Carousel c Nikon D700, автоматизирайки процеса за преснимане на рамкирани Аиапозитиви. Тази модификация е сравнима с мини лаб скенерите за не нарязани фрилми, тъй като може много бързо да Аигитализира огромен брой калри. Качеството е също така компромисно, но за архиви сьАьржащи хи^яли Аиапозитиви, може Аа бъле много полезно за преглеА и опис.

Обработката на получените изображения са втора стьпка в Аигитализацията, обикновено отнемаща и повече време. Photoshop ce е превърнал в символ на безграничните възможности и тук започва Аебатьт за Аопустимата обработка. Освен зальлжителните сгор и ретуш, останалите корекции са изключително субективно решение, как трябва Аа изглежла кальрьт. Присьствал сьм на релица обсьжАания, за това Ао каква степен имаме право да променяме образа, особени при архивните калри 22 . Проблемьт там се зальлбочава зарали стареенето на ^ентата с времето, както и често мипсата на автор, който би могьл $\Delta а$ знае какво оригинално е било изображението или какво е желал $\Delta а$ постигне. В моята работа с нови Аиапозитиви (сега съзАалени), трудността е най-вече в постигане на максимално близьк Аигитален образ на оригинала. Много често се врьщам и обработвам наново еАни и същи Аигитализации, постигайки различни резултати. Този ефрект е забелязан и от Гай Бърнс (Guy Burns) (Burns, 2009, p. 75):

"If you edit a scan to the best of your ability, but you are not convinced it really is the most pleasing image, what you can do is leave the image alone for several hours, make a copy of the raw scan, and then re-edit. This second version will almost certainly look different from the initial version, and the difference will point you in the direction of further improvements. On the other hand, if the two images look pretty much the same, you can be fairly confident that you really do have the most pleasing image (it is unlikely you would

$22 \mathrm{Ha}$ конореренцията "Balkan Cinema on the Crossroads: From Nitrate to Digital, Belgrade, Serbia: 11-13 June, 2017" Габор Пинтер (Gabor Pinter) изнесе Аоклал на тема "Ethical Restoration Dilemmas of Nitrate Balkan Films at the Hungarian FilmLab" (Етични Аилеми при реставрацията на нитратни балкански фрилми в Унгарската фрилмова лаборатория). В рамките на фестивала „3латна роза“ 2020 показаха Аигитализирано копие на фрилма "Мера според мера", който също предизвика бурни реакции зарали цветните корекции. 
have zeroed in on the same optimum endpoint with two independent edits)."

ПРЕВОА: Ако обработвате еАин скан Ао най-Аоброто, на което сте способни, но не сте напълно убелени, че това е найзадоволителния образ - това, което можете $А а$ направите, е Аа оставите за няколко часа снимката, $\Delta а$ направите копие на суровия скан и Аа обработите наново. Втората версия почти сигурно ще изглежАа различно от пьрвата и разликата ще ви покаже посоката на бъдещото усъвършенстване. От Аруга страна, ако Авете снимки изглежАат Аоста подобно, можете $А$ сте Аостатъчно сигурни, че имате най заловолителния резултат (не е вероятно Аа сте постигнали пьлно съвпаление на крайия

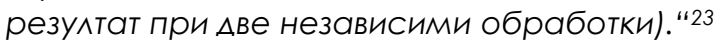

Колкото и парадоксално да звучи, практиката го Аоказва неАвусмислено и може Аа се вили от слеАния пример (фоиг.16):
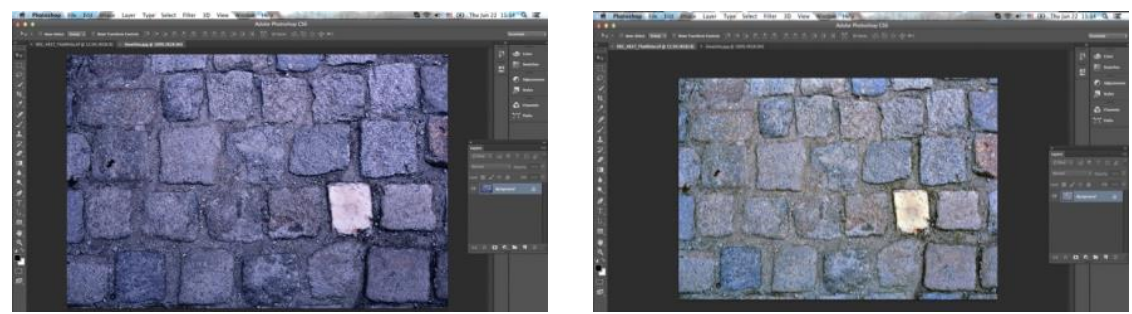

Фиг.16. Различна обработка на еАна и съща Аигитализация

И Авата кальра са правени с технологията на преснимане с фотоапарат, като отначало смятах втората Аигитализация за много поблизо Ао реалния Аиапозитив. Кьм момента сьм обработвал и Аигитализирал поне 4-5 пьти този каАьр отново и отново, преработваики цветни профиии и т.н., в стремежа си $\Delta$ а се Аоближа $\Delta о$ оригиналния

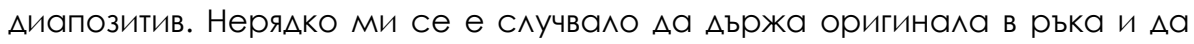
се опитвам безуспешно $а$ постигна същото на екрана.

Ето като Аопьлнителна референция и скан на същата серия снимки, на плоськ скенер, кьАето целта е $а$ а се вилят разликите в обективите, но се вижАа ясно и разликата в Аигитализацията (фриг.17):

23 Burns, Guy. (2009). The Art and Science of Reproducing Kodachrome, p. 75 (Burns, 2009, p. 75) 


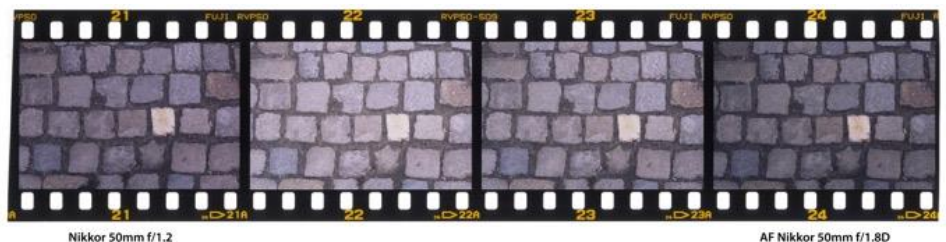

\section{Фиг.17. Серия сканирана заенно с перфорацията на плосък скенер}

Слелващата серия показва отново разлики в Аигитализирането през различни периоли от време и технологии. По-малкият скан в следващото сравнение (фоиг. 18) е от фотолаб, правен приблизително през 2006 г., с резолюция около 10 Мрх. ОтАясно е същият кальр, пресниман с оротоапарат Nikon D810, около 36 Mpх, през 2016 г. Освен резолюцията има вилима разлика в цветовете, Аинамиката и остротата.

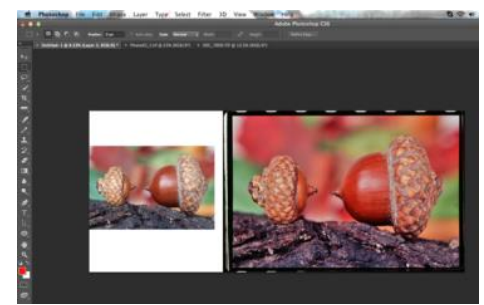

Фиг.18. ОтАяво - мини Ааб скан, ОтАясно - преснимано с Nikon D810

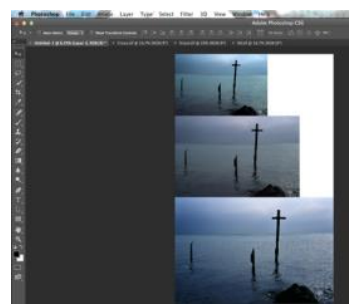

Фиг.19. Сравнение межау Imacon, Nikon Coolscan V ED, Nikon D810

Фигура 19 показва скан с Imacon скенер, 2007 г., около 10 Мрх; скан с Nikon Coolscan V ED, около 20 Mpх, 2013 г.; пресниман с фототопарат Nikon D810, около 36 Mpx, 2016 г. Фигура 20 показва отляво скан с Nikon Coolscan V ED, приблизително 2012 - 2013 г., около 20 Мрx; а вАясно - пресниман с фоотоапарат Nikon D810, около 36 Mpx, 2016 г.

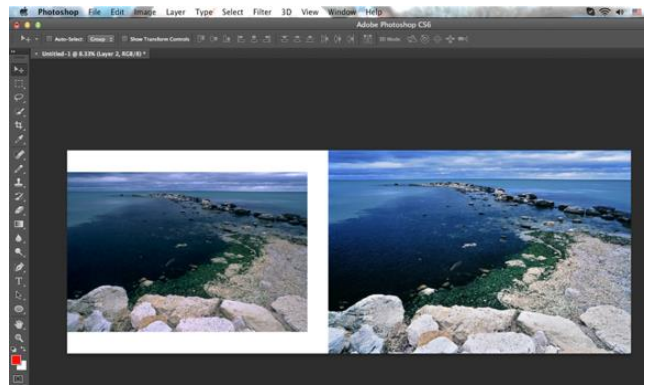




\section{Фиг.20. Сравнение межау Nikon Coolscan V ED и Nikon D810}

Сурови каАри - вляво Imacon, 2009 г., около 16 Мрх; вАясно пресниман с фротоапарат Nikon D810, около 36 Mpx, 2016 г. (фриг.21):

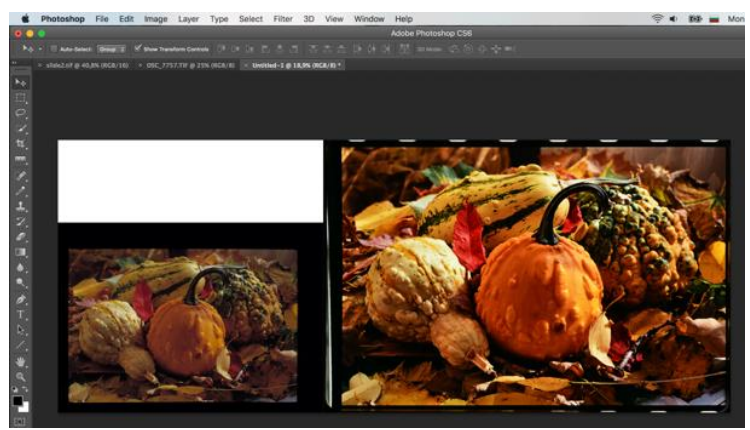

\section{Фиг.21. Сравнение межАу сурови каАри от Imacon и Nikon D810}

Всички тези тестове и примери могат $\Delta$ а се разработват в още по-големи детайли като тип използвана матрица (CCD, CMOS, Foveon), цветна компресия (8-, 14-, 16-bit), цветно пространство (sRGB, Adobe RGB), използвана оптика и т.н. почти Ао безкрайност. Но абстрахирайки се от чисто техническите характеристики, вярвам че визуално окото Аава най-Аобра оценка на резултата, особено при Аиректно сравнение с оригинала. Ао поАобен извол стига и ГайБьрнс (Guy Burns) на фринала на изследването си (Burns, 2009, p. 175):

"The reader would have noticed the term "most-pleasing" throughout this document. It means what looks most-pleasing to my eye after scanning and editing. Sharpness, shadow detail, colour and contrast are taken into account, but behind-the-scenes technicalities such as native resolution, bit-depth and IT8 profiles are of little importance. The image must be "most-pleasing".

"Читателят трябва $А$ е забелязал понятието „найзаАоволителен" в текста. То значи какво изглежАа найзаАоволително за мен, слеА сканиране и обработка. Острота, Аетайл в сенките, цвят и контраст са взети поА внимание, но в крайна сметка технологии като резолюция, бит и ІТ8 цветни профоили не са от голямо значение. Образът трябва $\Delta а$ бъле „най-заловолителен. "24

24 Burns, Guy. (2009). The Art and Science of Reproducing Kodachrome, p. 175 (Burns, 2009, p. 175) 
Критериите за това обаче са силно субективни. Моят опит показва, че описаната технология на преснимане, специално при 35мм Аиапозитив, Аава най-Аобри резултати към настоящия момент, без $\Delta а$ са абсолютни. При полобен трансорер от еАна медия към Аруга изображението неизбежно се променя. Съществуват и калри, които аз условно наричам "невъзможни за Аигитализация". Това са режимни снимки, гранични като експозиция или т. нар. „висок кАюч“, които АО момента не съм успял Аа прехвърля Аостатьчно Аобре, сравним с въздействието им по аналогов пьт.

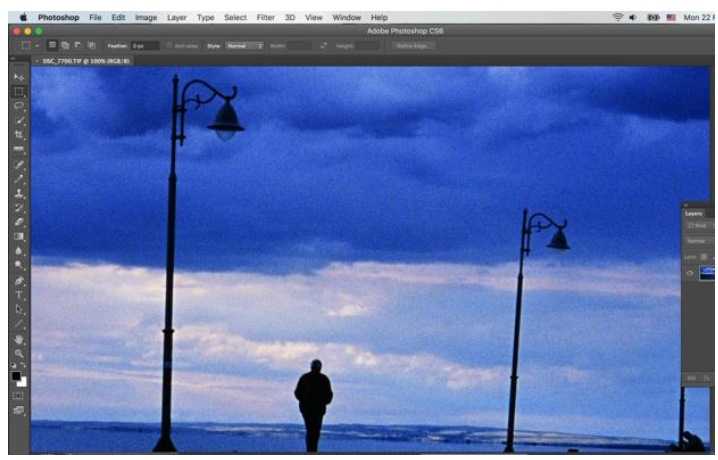

\section{Фиг.22. Високо ниво на шум, засилен контраст, ^ипса на полутонове}

При тях обикновено се засилва т. нар. „шум“, контраста е много висок, което разваля Аинамиката и цветопредаването, изгубва се мекотата и голямата тоналност на фиима. Всичко това АонякьАе може a а се коригира при обработката, но обикновено за сметка на нещо мруго. Усещането за разваляне на изображението вероятно е много субективно, но напьлно реално за автора като творческо намерение.

Съществува обаче и обратното - много често чрез обработка фотографите замаскират неуспехите си при снимане. Аигитализирането има безкрайно много възможности, без Аа има еАно вярно решение. СлеАват ^огичните вьпроси - какво всъщност вижАаме, когато гледаме Аигитализация на аналогово произведение? Каква част от оригинала възприемаме и с каква промяна? И трябва ми $а$ Аигитализираме? Отговорите са фуннкция от различни фрактори. На пьрво място Аигитализацията Анес е неизбежна - почти са изчезнали аналоговите технологии за тиражиране и показ, които преди бяха ежедневие. Без тази стьпка е практически невъзможно $а$ с се разпространява ими печата. Нещо повече - в съвремието ни публиката вьзприема почти единствено и само 
Аигитални образи. Все по-малко и по-рядко хората имат Аосег с оригинали и Аори печатни медии. Образите, които Аостигат Ао нас, са резултат от избор на Аигитализация, обработка и екран, които фринално изгражАа виАимото от нас изображение. ЕАно и също изображение изглежАа различно на компютьрен екран, на таблет, телефрон или прожектирано на голям екран. Аюбимият ми пример е еАна снимка на фотографра от National Geographic - Ажим Бранденбьрг (Jim Brandenburg), койо прави серия снимки на самотен вьлк среА плаващи блокове ^еА. За пьрви пьт виАях тази впечатляваща фротография по време на изложба в Националната галерия в Соория и когато я потьрсих в интернет, попаднах на поне 3-4 вариации:

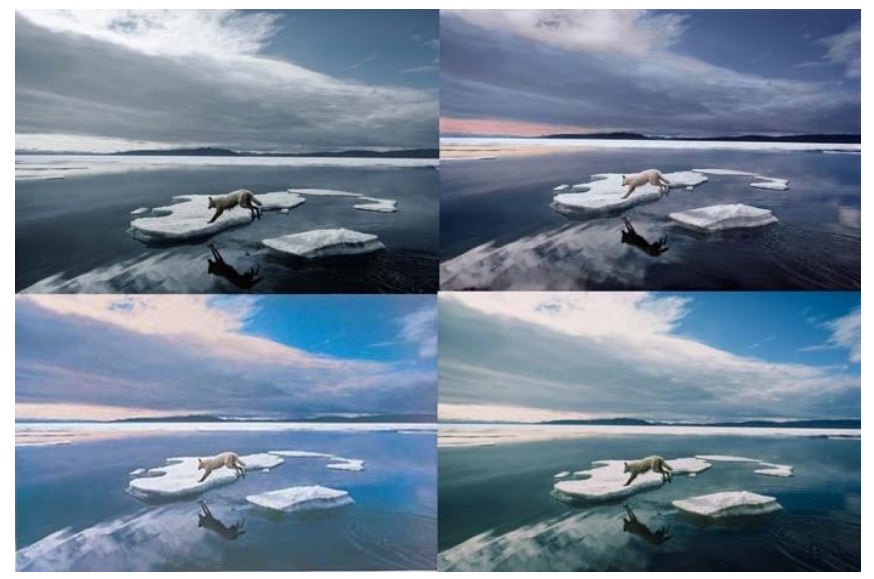

Фиг.23. Вариации на каАъра на Ажим Бранденбърг (Jim Brandenburg)

Коя е най-близо Ао истинския кальр, можем само да галаем. СъзАалена през 90-те години, снимката е разбира се на фрилм. В крайна сметка специалистите по печат говорят за „преАвиАими“25 резултати, а Гай Бърнс (Guy Burns) - за „най-заловолителни“ (Burns, 2009, р. 175). Което по същество е признание за огромната относителност на Аигиталните процеси и невьзможност за получаване на инвариантност, а само на АОнякьАе преАвиАим, заАоволителен, спореА нечии критерии, резултат. Може би това е и причината много фотографри, в това число и аз, все още $л а$ предпочитат за определени художествени цели аналоговите технологии, които вьпреки своите недостатьци, често пьти съзАават еАин-

25 Управление на цвета и подбор на медии за фротографрски печат с Георги Чакъров, https://www.youtube.com/watch?v=N4SL8TkLXto (Viewed at 23-02-2021) 
еАинствен оригинал, необвьрзан с конкретен технологичен етап, към резолюция, цветно колиране или фраилова компресия, които Аа остават така Аигитално замръзнали във времето, без да се възприемат пряко от зрителя. И макар фрилмьт и фотографоските оригинали Аа имат много Аруги несъвьршенства и Аа стареят с годините, при правилно съхранение позволяват $\Delta а$ се Аигитализират отново, при всяка слеАваща технологична стьпка. Като все още несъмнено оригинальт остава найценен. Никой не може Аа каже и каква ще бъле следващата стьпка, кьм която вероятно ще се наложи Аа прехвърляме отново изображенията.

\section{LITERATURE ( $\triangle$ UTEPATYPA)}

Burns, Guy. (2009). The Art and Science of Reproducing Kodachrome, http://www.mediafire.com/download.php?qc67n2gkdz3viyp

Harris, P. W. (1954). One Hundred Years of Colour Photography, RPS Journal, Volume 94, p. 46-59, https://archive.rps.org/archive/volume-94 The Royal Photographic Society Journal, https://archive.rps.org

Institute of Art Studies at the Bulgarian Academy of Sciences 

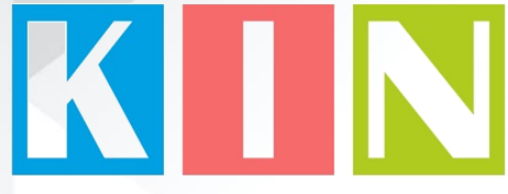

\section{ISSN: 2367-8038}

\section{Съставители \\ Петко Ст. Петков \\ Галина БогАанова}

Материалите в сборника са обект на авторско право. Разрешава се безвъзмезАното ползване на техни електронни/ хартиени копия само за мична употреба или обучение, при пьлно цитиране на текущата страница и слеА писмена Аек^арация от цитиращия за ^ипса на търговски намерения.

Научната поредица е регистрирана в НАЦИА С № 1209

() Авторски колектив, 2021

Техническо реАактори: Калина Сотирова-Вълкова Николай Ноев Паска^ Пиперков

\section{Editors}

Petko St. Petkov

Galina Bogdanova

This work is subject to copyright.

Open and free of charge use of digital/hard copies of publications is granted only for personal or educational use, with full citation of the current page, and after written declaration of the quoting side for notcommercial Intention.

Science series has been registered in NACID with No. 1209

() Authors` Group, 2021

Technical editors:

Kalina Sotirova-Valkova

Nikolay Noev

Paskal Piperkov

\section{ISSN: 2367-8038}

том 7, брой $1(10) / 2021$

vol. 7 , issue $1(10) / 2021$ 